\title{
ELECTROCHEMICAL BIOSENSOR BASED ON MODIFIED REDUCED GRAPHENE OXIDE WITH SILVER NANOPARTICLES FOR DETECTION OF METHYLATED DNA
}

\author{
1,2Eliska SEDLACKOVA, ${ }^{1}$ Eliska BIRGUSOVA, 1,2Zuzana BYTESNIKOVA, ${ }^{1}$ Pavel SVEC, \\ 1,2Lukas RICHTERA, 1,2Vojtech ADAM \\ ${ }^{1}$ Department of Chemistry and Biochemistry, Mendel University in Brno, Czech Republic, EU \\ ${ }^{2}$ Central European Institute of Technology, Brno University of Technology, Brno, \\ Czech Republic, EU
}

https://doi.org/10.37904/nanocon.2019.8610

\begin{abstract}
DNA methylation is one of the most studied and basic epigenetic process related to several diseases such as diabetes, neurodegenerative or cardiovascular diseases and even cancer. Methylated DNA presents a new generation of biomarkers which can be used for point-of-care detection. Electrochemical biosensors provide simple, fast, cost-effective, easy-to-use, reliable and efficient detection in contrast with conventional diagnostic methods. These biosensors can be used for early diagnosis of mentioned diseases and increase patient recovery by early clinical interventions. In this study, methylated DNA was detected electrochemically by the developed biosensor. The bare gold electrode was modified by drop-casting reduced graphene oxide with silver nanoparticles which enhance electrochemical signal due to their strong affinity to thiol modified DNA probe via a disulfide bridge. Afterwards, the sensitivity and selectivity of the nanocomposite were examined. The faradic electrochemical impedance spectroscopy was used for determination of the hybridization of the DNA probe with a methylated DNA sequence. The fabricated biosensor shows promising analytical features with a wide detection of the linear range.
\end{abstract}

Keywords: Reduced graphene oxide, silver nanoparticles, nanomaterials, methylated DNA, electrochemical biosensor

\section{INTRODUCTION}

Epigenetics deals with modifications that inherently affect gene expression without altering the primary genetic information, especially the nucleotide sequence in the DNA. These modifications include DNA methylation, histone modification, chromatin remodelling and posttranscriptional gene regulation by miRNA. DNA methylation plays a crucial role in the regulation of several biological processes. Moreover, methylated DNA is associated with several diseases including cancer [1]. Early treatment of cancer requires preventive and accurate diagnosis, which is very expensive, time-consuming, requires specialized staff and complicated instrumentation and only can be performed in the hospitals [2]. Every year in the Czech Republic, nearly 100,000 of the world population suffer from malignant carcinoma, and last year nearly 30,000 people died because of cancer. However, due to the lack of rapid diagnostics, these numbers are rapidly increasing. The number of newly diagnosed patients is expected to increase rapidly in the coming years. Recent studies [3, 4, 5] show that methylated DNA is a new generation of biomarkers, which are a promising alternative for use in both clinical diagnostics and therapy [6]. Nevertheless, classical methods are expensive, time-consuming and require skilled staff. On the other hand, electrochemical biosensors are promising for clinical diagnosis and can be used as analytical tools in the point-of-care application.

The proposed work was aimed to create a simple and universal biosensor for the detection of DNA methylation and M. Sss/ activity assay. To achieve the better sensitivity and selectivity was used the nanocomposite 
consisted from reduced graphene oxide with silver nanoparticles (rGO-AgNPs), because of the good chemical stability and ability to facilitate electron transfer between electrodes and biomolecules [7].

\section{MATERIAL AND METHODS}

\subsection{Reagents}

In this study were used synthetics oligonucleotides DNA_1: HS- $\left(\mathrm{CH}_{2}\right)_{6}-5$ '-CCT CGT GCG GGA TCA TTG TTA TTA GGCA-3' and DNA_2: 3'-GGA GCA CGC CCT AGT AAC AAT AAT CCGT-5', enzymes: CpG MTase

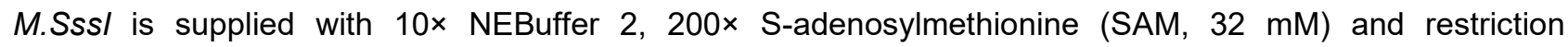
endonuclease Hpall with 10× CutSmart buffer (Thermo Fisher), methylene blue (MB) chemicals for buffer preparation: sodium hydroxide $(\mathrm{NaOH})$, potassium sulfate $\left(\mathrm{K}_{2} \mathrm{SO}_{4}\right)$, potassium hexacyanoferrate(III) $\left(\mathrm{K}_{3}\left[\mathrm{Fe}(\mathrm{CN})_{6}\right]\right)$, potassium hexacyanoferrate $(\mathrm{II})\left(\mathrm{K}_{4}\left[\mathrm{Fe}(\mathrm{CN})_{6}\right]\right)$, sodium dihydrogen phosphate $\left(\mathrm{NaH}_{2} \mathrm{PO}_{4}\right)$ and sodium phosphate dibasic $\left(\mathrm{Na}_{2} \mathrm{HPO}_{4}\right)$. Reagents for the synthesis of $\mathrm{GO}$ and rGO-AgNPs: silver nitrate solution $\left(\mathrm{AgNO}_{3}\right), 37 \% \mathrm{HCl}$, potassium permanganate $\left(\mathrm{KMnO}_{4}\right)$, sodium borohydride $\left(\mathrm{NaBH}_{4}\right)$ and $\mathrm{H}_{2} \mathrm{O}_{2}$. All used chemicals were obtained from Sigma-Aldrich (St. Louis, MO, USA) unless otherwise stated. High purity deionized water (Milli-Q Millipore $18.2 \mathrm{M} \Omega \cdot \mathrm{cm}^{-1}$, Bedford, MA, USA) was used throughout the study.

\subsection{Synthesis of GO and rGO-AgNPs}

GO was prepared by chemical oxidation of $5 \mathrm{~g}$ graphite flakes (100 mesh, $\geq 75 \% \mathrm{~min}$ ) in a mixture of concentrated $\mathrm{H}_{2} \mathrm{SO}_{4}(670 \mathrm{ml})$ and $30 \mathrm{~g} \mathrm{KMnO}_{4}$ according to the simplified Hummer's method [8]. The reaction mixture was stirred vigorously. After 4 days, the oxidation of graphite was terminated by the addition of $\mathrm{H}_{2} \mathrm{O}_{2}$ solution $(250 \mathrm{ml}, 30 \mathrm{wt} \%)$. Formed $\mathrm{GO}$ was washed 3 times with $1 \mathrm{M} \mathrm{HCl}(37 \mathrm{wt} \%)$ and several times with Milli-Q water (total volume used $10 \mathrm{I}$ ) until constant $\mathrm{pH}$ value (3-4) was achieved. Afterwards, the $1 \mathrm{ml}$ of GO solution $\left(5 \mathrm{~g}^{-1}\right)$ was added dropwise into the $50 \mathrm{ml}$ of $\mathrm{AgNO}_{3}(10 \mathrm{mM})$ under vigorous stirring. After that 40 mg of sodium borohydride $\left(\mathrm{NaBH}_{4}\right)$ was added slowly to the reaction mixture and the resulting mixture was stirred intensively for $24 \mathrm{~h}$ to allow reduction. The final composite was washed with Milli- $\mathrm{Q}$ water several times.

\subsection{The procedure of electrode surface preparation}

Firstly, the bare gold electrode (GE) with a $2 \mathrm{~mm}$ radius (Ch Instruments Inc., Austin, USA) was mechanically and electrochemically polished. The three bare GEs were firstly sonicated in ultrasonic cleaner Elmasonic $\mathrm{P} 60 \mathrm{H}$ (Singen am Hohentwiel, Germany) for 15 mins in ethanol (EtOH) and then mechanically polished on a polishing pad (Buehler) with water-based diamond suspension and an alumina slurry. As the last step were electrodes cleaned electrochemically in $0.5 \mathrm{M} \mathrm{H}_{2} \mathrm{SO}_{4}$ by 50 scans of $\mathrm{CV}$ by potential scanning between $-0.05 \mathrm{~V}$ and $+1.1 \mathrm{~V}$. The GEs were rinsed with Milli- $Q$ water.

\subsection{Biosensor development}

The proposed biosensor was fabricated step by step as it described in Scheme 1. Firstly, the $5 \mu$ of rGOAgNPs was drop-casted onto the surface and let it dry. Then the $1 \mu \mathrm{M}$ DNA_1 was immobilised onto rGOAgNPs and let it incubate overnight in the fridge $\left(4{ }^{\circ} \mathrm{C}\right)$. After incubation, the DNA_1 hybridized with $100 \mathrm{nM}$ DNA_2. While the hybridization was successful, the electrode was treated by enzyme M. Sss/ methyltransferase, which added the methyl groups $\left(-\mathrm{CH}_{3}\right)$ to the fifth carbon of cytosine. At least the restriction Hpall, which blocked the cleaving at a specific site. To evaluate the sensitivity of developed biosensor, the $M$. Sss/ activity was tested. The modified GE was treated by a different concentrations of $M$. SssI $(5 ; 25 ; 50 ; 100$; 200; 300; 400 and $500 \mathrm{U} \cdot \mathrm{ml}^{-1}$ ) and measured in $20 \mu \mathrm{M} \mathrm{MB}$ solution. 


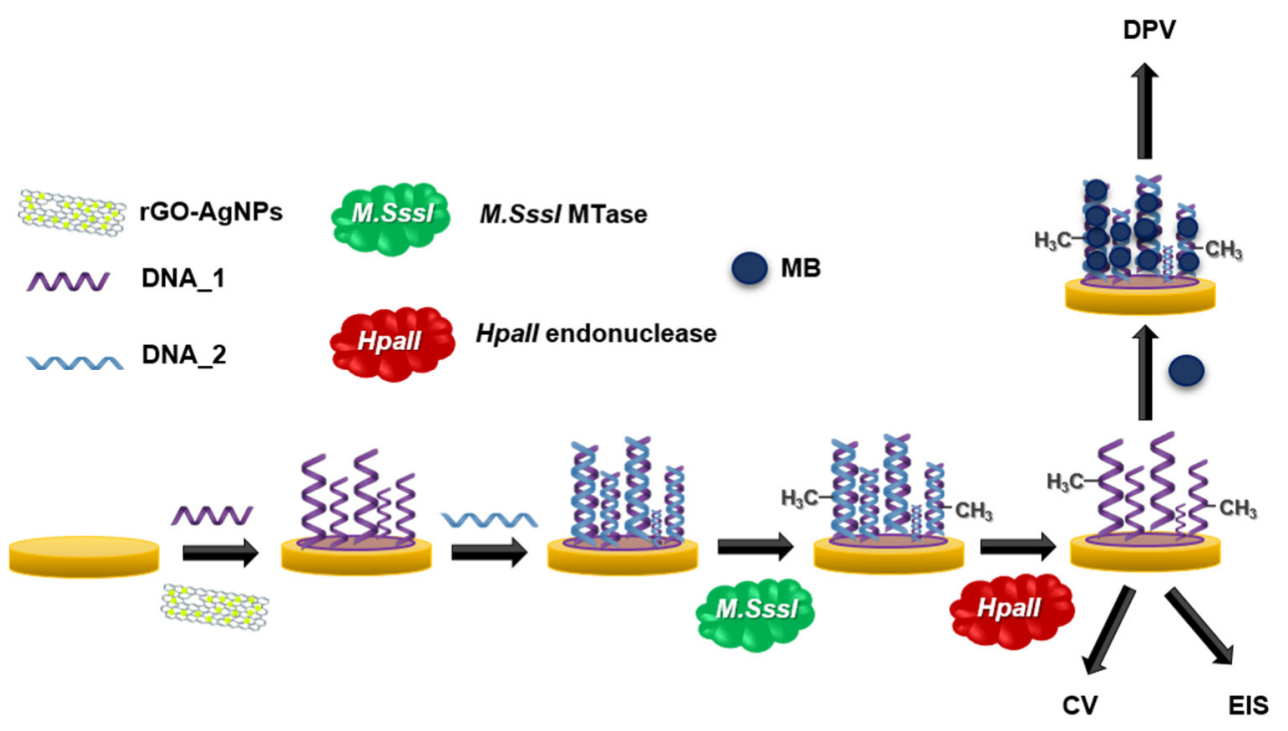

Scheme 1 Step by step of the biosensor fabrication

\subsection{Electrochemical measurements}

Synthesised rGO-AgNPs was evaluated via scanning electrochemical microscopy (SEM). Process of biosensor development was characterised via electrochemical impedance spectroscopy (EIS) in Faradaic mode, with a frequency range from $100 \mathrm{kHz}$ to $100 \mathrm{MHz}$. All the electrochemical measurements were performed in a standard three-electrode system. Sensitivity and reliability were characterised by differential pulse voltammetry (DPV). EIS and DPV were performed in $5 \mathrm{mM} \mathrm{Fe}(\mathrm{CN}) 6^{4-} / \mathrm{Fe}(\mathrm{CN}) 6^{3-}$ diluted in $100 \mathrm{mM}$ phosphate buffer (PB, pH 7.0). Parameters of DPV were following: potential range from $0.0 \mathrm{~V}$ to $-0.6 \mathrm{~V}$, amplitude $0.02 \mathrm{~V}$ and scan-rate $0.015 \mathrm{~V} \cdot \mathrm{s}^{-1}$

\section{RESULTS AND DISCUSSION}

\subsection{Synthesis of GO and rGO-AgNPs}

AgNPs were stabilized on the GO surface by using $\mathrm{NaBH}_{4}$ as a reducing agent. The resulting material is rGO-Ag nanocomposite with uniformly distributed AgNPs onto rGO. The morphology of nanocomposite rGO-Ag was observed using SEM (Figure 1).

Figure 1 SEM picture of the rGO-AgNPs nanocomposite

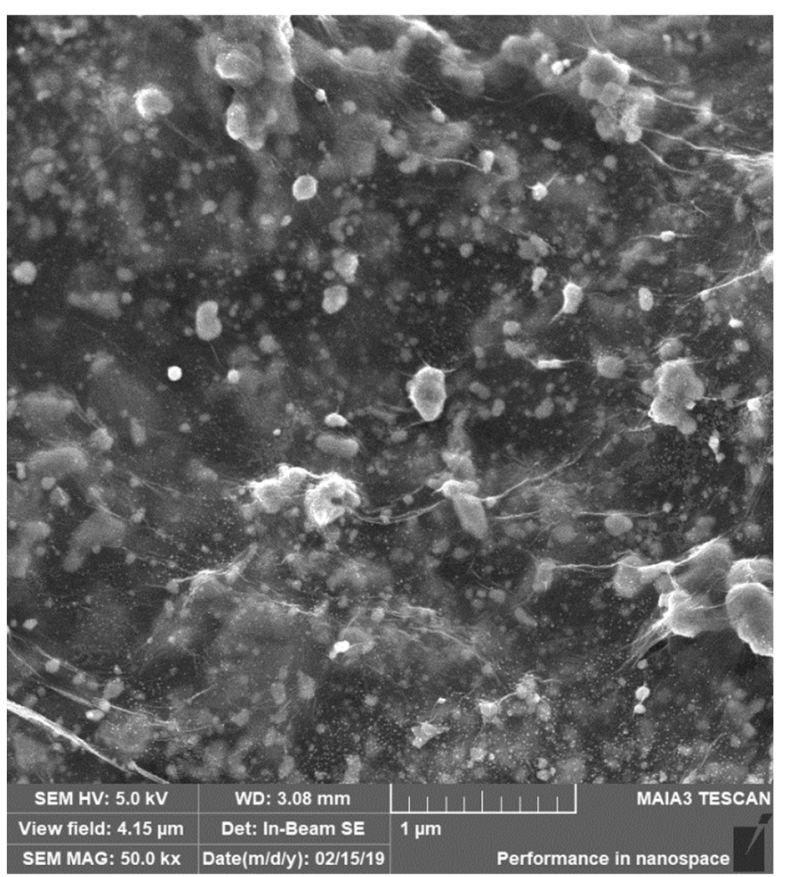




\subsection{Electrochemical performance of the developed biosensor}

The modified surface of GE by rGO-AgNPs nanocomposite was characterized by Electrochemical Impedance Spectroscopy (EIS). Recorded Nyquist plots (Figure 3) show increasing charge transfer value due to the change between redox potential and the GE surface. Moreover, the sensitivity of the proposed biosensor was obtained by differential pulse voltammetry (DPV). The linear equation was obtained from calibration curve $I(\mu \mathrm{A})$ $=-0.0005 \mathrm{c}(\mathrm{U} / \mathrm{ml})-0.1003 ;\left(R^{2}=0.9922\right)$ and has shown a broad linear range from $5 \mathrm{U} / \mathrm{ml}$ to $500 \mathrm{U} / \mathrm{ml}$ of $M$. Sssl. The error bars were calculated as a standard deviation from measurement $(n=3)$.
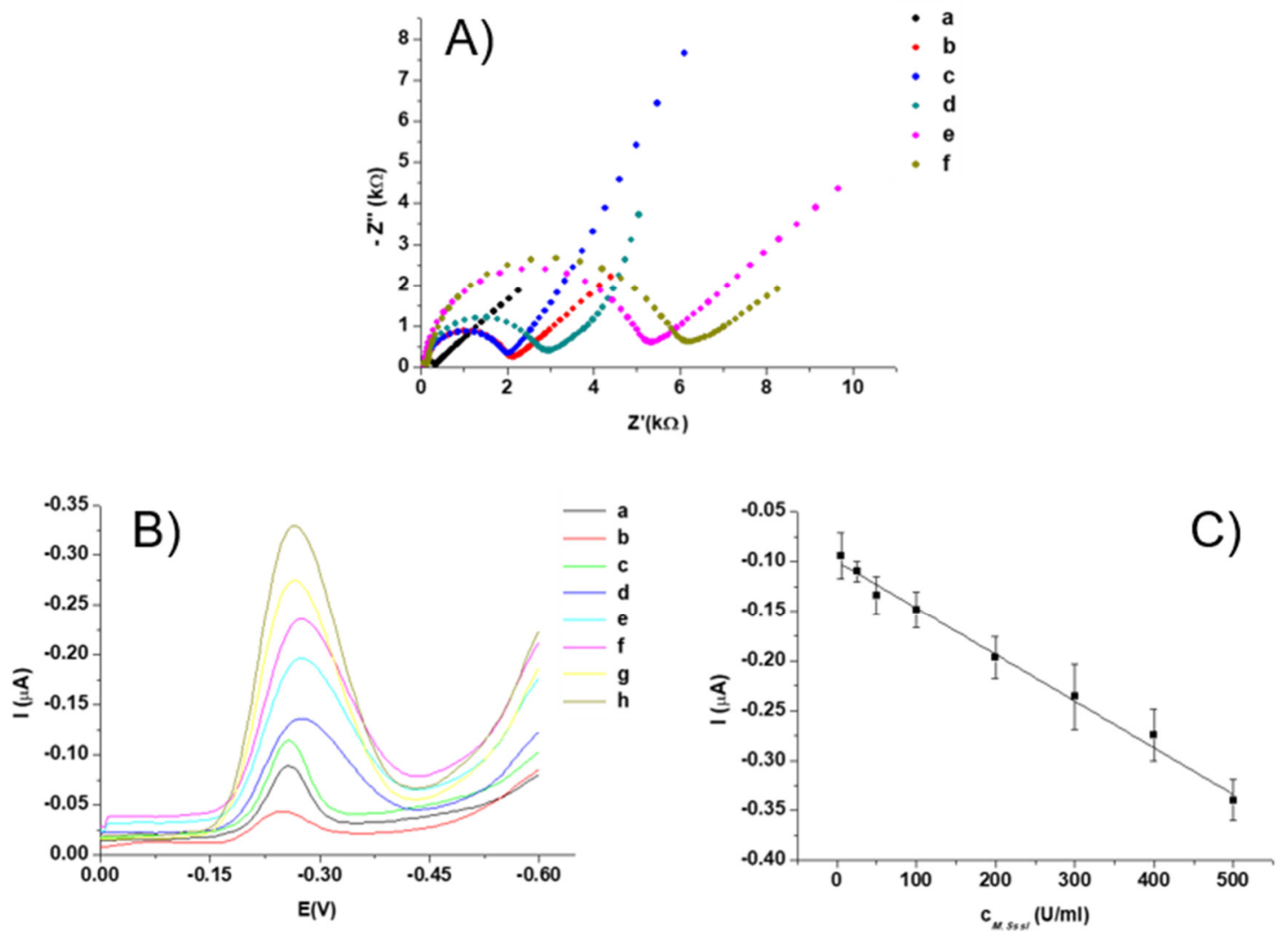

Figure $2 \mathrm{~A}$ ) Nyquist plots obtained from EIS measurement in $5 \mathrm{mM} \mathrm{Fe}(\mathrm{CN})_{6}^{4-} / \mathrm{Fe}(\mathrm{CN})_{6} 6^{3-}$ in $100 \mathrm{mM} \mathrm{PB}$. (a) The bare GE, (b) GE/rGO-AgNPs, (c) GE/rGO-AgNPs/DNA_1, (d) GE/rGO-AgNPs/probe DNA_1/ DNA_2, (e) GE/rGO-AgNPs/DNA_1/ DNA_2/ M. Sss/ MTase (500 U/ml)/ Hpall $\left(20 \mathrm{U} \cdot \mathrm{ml}^{-1}\right)$ and (f) GE/rGO-AuNPs/ DNA_1/ DNA_2/ M. Sss/ MTase $\left(500 \mathrm{U} \cdot \mathrm{ml}^{-1}\right)$. B) DPV records obtained from various concentrations measurement. The DNA was methylated by $5 ; 25 ; 50 ; 100 ; 200 ; 300 ; 400$ and $500 \mathrm{U} / \mathrm{ml} \mathrm{M}$. Sssl. C) Calibration curve responds to the accumulated MB in the helix structure. Error bars were calculated in dependence on standard deviations from the measurement.

\section{CONCLUSION}

Herein, a simple and sensitive biosensor for specific detection of DNA methylation and $M$. Sss/ MTase was fabricated. The biosensor modified with rGO-AgNPs nanocomposite has shown the determination of $M$. Sss/ with a broad linear range from $5 \mathrm{U} \cdot \mathrm{ml}^{-1}$ to $500 \mathrm{U} \cdot \mathrm{ml}^{-1}$. Our biosensor provides an easy measurement of DNA methylation. The main advantage of this is, that it does not require expensive instruments, PCR amplification and multiple-step procedures. From the preliminary data is obvious, that our biosensor can be easily transferred to lab-on-a-chip and be part of smart device, which will be created in the future. 


\section{ACKNOWLEDGEMENTS}

The research was financially supported by the IGA MENDELU AF-IGA2019-IP059 and carried out under the project CEITEC 2020 (LQ1601) with financial support from the Ministry of Education, Youth and Sports of the Czech Republic under the National Sustainability Programme II.

\section{REFERENCES}

[1] YIN, H., ZHOU, Y., XU, Z., CHEN, L., ZHANG, D., Al, S. An electrochemical assay for DNA methylation, methyltransferase activity and inhibitor screening based on methyl binding domain protein. Biosensors and Bioelectronics. 2013, no. 41, pp. 492-497.

[2] HUANG, R., HE, N., LI, Z. Recent progresses in DNA nanostructure-based biosensors for detection of tumor markers. Biosensors and Bioelectronics. 2018, no109, pp. 27-34.

[3] COHEN, J., PIVODIC, L., MICINESI, G., ONWUTEAKA-PHILIPSEN, B. D., NAYLOR, W. A., WILSON, D. M., RUIZ-RAMOS, M. International study of the place of death of people with cancer: a population-level comparison of 14 countries across 4 continents using death certificate data. British journal of cancer. 2015, vol. 113, no. 9, pp 1397.

[4] WU, J., SHUANG, Z., ZHAO, J., TANG, H., LIU, P., ZHANG, L., XIAO, X. Linc00152 promotes tumorigenesis by regulating DNMTs in triple-negative breast cancer. Biomedicine \& Pharmacotherapy. 2018, no. 97, pp. 12751281.

[5] FIDLER, M. M., SOERJOMATARAM, I., BRAY, F. A global view on cancer incidence and national levels of the human development index. International journal of cancer. 2016, vol. 139, no. 11, pp. 2436-2446.

[6] POVEDANO, E., VARGAS, E., MONTIEL, V. R. V., TORRENTE-RODRÍGUEZ, R. M., PEDRERO, M., BARDERAS, R., CAMPUZANO, S. Electrochemical affinity biosensors for fast detection of gene-specific methylations with no need for bisulfite and amplification treatments. Scientific reports. 2018 , vol. 8 no. 1 , pp. 6418 .

[7] WAN, Y., WANG, Y., WU, J., ZHANG, D. Graphene oxide sheet-mediated silver enhancement for application to electrochemical biosensors. Analytical chemistry. 2010, vol. 83, no. 3, pp. 648-653.

[8] HUMMERS, W. S., OFFENMAN, R. E. Preparation of graphitic oxide. Journal of the american chemical society, 1958, vol. 80 , no. 6 , pp. 1339-1339. 